https://doi.org/10.52240/1857-2367.2020.2(21).35

\title{
AGASTACHE URTICIFOLIA (BENTH.) KUNTZE - AROMATIC PLANT INTRODUCED AND RESEARCHED IN THE BOTANICAL GARDEN
}

\author{
Alina BOGDAN, Maricica COLȚUN \\ "Al. Ciubotaru” National Botanical Garden (Institute), \\ Chisinau, Republic of Moldova
}

\begin{abstract}
This paper includes the results of the research on some aspects of the introduction of Agastache urticifolia (Benth.) Kuntze., its biological characteristics and essential oil content. The species under study is a perennial, herbaceous plant in the Lamiaceae family. In the Botanical Garden, it has been researched as aromatic and medicinal plant. It has high ecological plasticity and does not have special requirements for climatic factors. It is used for its aromatic properties and, in medicine, as an immunostimulant, tonic, antiinflammatory and antispasmodic remedy.
\end{abstract}

Key words: aromatic, species, introduction, content, essential oil.

Agastache urticifolia (Benth.) Kuntze - is a species in the mint family, known by the common name nettleleaf giant hyssop or horse mint. It is native to western North Amer- 
ica, from British Columbia and California to Colorado, where it grows in many habitat types. It is an aromatic plant, which under the climatic conditions of Moldova, develops 4-6 erect stems and grows about 0.80-1.2 $\mathrm{m}$ tall, has very widely spaced leaves, lanceshaped to nearly triangular and toothed. The leaves are up to $8 \mathrm{~cm}$ long and $6 \mathrm{~cm}$ wide. The inflorescence is a dense spike of many flowers. Each flower has long sepals tipped with bright purple and tubular corollas. The plant is tolerant of soils with low humidity, as well as temperature variations. The essential oil is the biologically active substance in this plant; it is used in perfumery and cosmetics, pharmaceutical industry, aromatherapy and gastronomy. The species has been researched in the Botanical Garden in order to identify the biological peculiarities of development and to determine the essential oil content. The original seed material was received from Germany.

In the first year of vegetation, the plants were characterized by slow development, reaching at the beginning of July only $5-6 \mathrm{~cm}$ in height; they did not reach the generative phase. The perennial plants ( 3 years), under the conditions of the reference year, started growing in late March. An intensive development of the plants was observed until the budding phase, which was noted at the beginning of June, when they reached a height of $80-90 \mathrm{~cm}$. The generative stems, which were about 8-10 in total, developed up to 12-14 second-order branches. The first flowers on the central axis appeared at the end of July. Full flowering was observed in 7-8 days, when the plants reached a height of $95-110 \mathrm{~cm}$. The plants bloomed throughout the summer. The seeds ripened in early October. The full flowering stage lasted 70 days. The perennial plants of Agastache urticifolia were able to complete, under the conditions of the Republic of Moldova, the entire development cycle, which lasted 200-220 days.

Agastache urticifolia can be propagated generatively (by seedlings) and vegetatively (by division). Seed germination, after a 5-month storage, under laboratory conditions, was $60-65 \%$. To obtain seedlings, the sowing in the greenhouse was carried out in late February to early March. In 30-40 days, the seedlings grew 5-7 cm tall, with 2-4 leaves and a well-developed root system. At the beginning of May, they were transplanted in open ground, the rooting percentage of the seedlings being 70-75\%. During the summer, the plants developed slowly, forming 1-2 stems with 4-6 pairs of first-order branches, each with 4-5 pairs of leaves, the leaf blade length was 4.5-6.5 $\mathrm{cm}$ and the width $3-4 \mathrm{~cm}$. The plants reached a height of $50-55 \mathrm{~cm}$ at the end of August. The first buds appeared in September, some reaching the beginning of the flowering stage. Flowers are a great attraction for bees and butterflies. Their scent is similar to that of anise.

Agastache urticifolia plants accumulated essential oil throughout the growing season, but its amount varied depending on the age of the plant and the stage of development. According to data from the literature, the research on the dynamics of essential oil content has shown that plants, in the first year of development, produced the lowest amount of oil $(0.30-0.32 \%)$. Starting with the second year, when the physiological processes intensified, the amount of oil increased (0.45-0.48\%). In the third year of vegetation, the content of essential oil in A. urticifolia was 0.30-0.60\% [2]. In the current year, the essential oil content of the species $A$. urticifolia in the full flowering stage, in 3 -year-old plants, was $0.45-0.49 \%$, respectively $1.65-1.70 \%$ in the dry matter. Thus, the perennial plants of $A$. urticifolia were able to complete the entire vegetation cycle under 
the climatic conditions of the Republic of Moldova, being a promising species for phytocosmetics, phytotherapy and aromatherapy. The plant is also used to flavor liqueurs. [1]

Highlighting and researching some promising aromatic species and the gradual expansion of the cultivation area of these species open new ways of identifying effective measures to promote health, beauty and prevention of diseases in a natural way.

The research was supported by the NARD through the project "Research and conservation of vascular flora and macromycobiota of the Republic of Moldova", 20.80009.7007.22 (contract Nr. 71/PS/2020).

\section{BIBLIOGRAPHY}

1. Andrea Rasch, Brigitte Lotz. Plante aromatice. Bucureşti, 2010, p. 23

2. Бодруг. М. В. Интродукция новых эфирномасличных растений в Молдове Кишинев. “Штиинца" 1993, 144 р. 